\title{
Gevolgen van vernietiging van B2C- overeenkomsten bij conforme zaken en diensten, in het bijzonder in het geval van prijspersonalisatie
}

\author{
Mr. T.J.de Graaf*
}

\section{Introductie}

Door ontwikkelingen in big data, bandbreedte, opslag, kunstmatige intelligentie en rekenkracht wordt het steeds makkelijker de prijs van een goed of dienst (hierna: $\operatorname{product}^{1}$ ) af te stemmen op wat een individuele consument daar maximaal voor wil betalen. Prijspersonalisatie is dat afstemmen. ${ }^{2} \mathrm{Er}$ is al veel onderzoek verricht naar de vraag of prijspersonalisatie wenselijk en toelaatbaar is op grond van consumenten- en privacyrecht. ${ }^{3} \mathrm{Er}$ is echter minder onderzoek verricht naar de vol-

\footnotetext{
Mr. T.J. de Graaf is universitair hoofddocent burgerlijk recht aan de Universiteit Leiden en redacteur van dit tijdschrift.

Dit onderzoek is gefinancierd door middel van het onderzoeksproject Interaction between Legal Systems (ILS) van de Universiteit Leiden, in het bijzonder het project 'Data use, online consumer needs, business strategies and regulatory response', geleid door professoren Willem van Boom, Simone van der Hof \& Jean-Pierre van der Rest. Deze bijdrage is een bewerking van T.J. de Graaf, Consequences of Nullifying an Agreement on Account of Personalised Pricing, Journal of European Consumer and Market Law (EuCML) 2019, afl. 5, p. 184-193. Degenen die geïnteresseerd zijn in een rechtsvergelijking met Belgisch recht verwijs ik naar dit Engelstalige artikel.
}

1. 'Product' wordt gedefinieerd als 'een goed of dienst, met inbegrip van onroerend goed, rechten en verplichtingen' in art. 2 onder (c) van de Richtlijn 2005/29/EG van het Europees Parlement en de Raad van 11 mei 2005 betreffende oneerlijke handelspraktijken van ondernemingen jegens consumenten op de interne markt en tot wijziging van Richtlijn 84/450/EEG van de Raad, Richtlijnen 97/7/EG, 98/27/EG en 2002/65/EG van het Europees Parlement en de Raad en van Verordening (EG) 2006/2004 van het Europees Parlement en de Raad (richtlijn OHP).

2. Volgens een OESO-rapport is prijspersonalisatie (vrij vertaald): 'elke vorm van prijsdiscriminatie van eindgebruikers op basis van hun persoonlijke kenmerken en gedrag, waardoor prijzen worden vastgesteld op basis van de bereidheid van consumenten daarvoor te betalen (...)', zie OESO, Background Note by the Secretariat. Personalised Pricing in the Digital Era, oecd.org/daf/competition/personalised-pricing-in-the-digitalera.htm, par. 17-19, waarin prijspersonalisatie onderscheiden wordt van dynamische prijsstelling (waarmee prijzen, vaak realtime, worden aangepast aan veranderingen in vraag en aanbod) en andere vormen van online prijsstelling.

3. Zie het OESO-rapport genoemd in noot 2, Europese Commissie, Richtsnoeren voor de tenuitvoerlegging/toepassing van Richtlijn 2005/29/EG betreffende oneerlijke handelspraktijken, SWD (2016) 163 final, par. 5.2.13 en J.P. Poort \& F.J. Zuiderveen Borgesius, Prijsdiscriminatie, privacy, en publieke opinie, AA 2019, p. 580-590. gende vraag: stel dat een individuele consument ${ }^{4}$ een overeenkomst kan vernietigen die onder invloed van prijspersonalisatie tot stand is gekomen, wat zijn dan de gevolgen van die vernietiging?5 De beantwoording van deze vraag is relevant omdat de EU het aan individuele EU-lidstaten heeft overgelaten sancties vast te stellen die van toepassing zijn op schending van nationale wetgeving ter implementatie van EU-richtlijnen waarop zo'n vernietigingsbevoegdheid wordt gebaseerd (waarover meer in par. 2), en die sancties 'doeltreffend, evenredig en afschrikwekkend' moeten zijn. ${ }^{6}$ Als uit onderzoek blijkt dat de gevolgen van vernietiging niet doeltreffend, evenredig en afschrikwekkend zijn, maar misschien zelfs dode letters, dan moeten andere sancties worden opgelegd, zoals schadevergoeding op grond van onrechtmatige daad of handhaving door toezichthouders. ${ }^{7}$ Het bestaan van dergelijke sancties kan heel wel tot de conclusie leiden dat hoewel bepaalde individuele

4. Ik realiseer me dat individuele acties waarschijnlijk niet erg praktisch zijn als het nadeel of de schade gering is, maar een analyse van individuele acties is desalniettemin zinvol, omdat die vaak een voorwaarde voor of voorloper van een collectieve actie zijn. Zie voor een bespreking van collectieve handhaving en algemenere acties die leiden tot vernietiging (bijv. gebaseerd op dwaling of fraude) W.H. van Boom, Inpassing en handhaving van de Wet oneerlijke handelspraktijken, TvC 2008, afl. 1, p. 4-23.

5. Zie ook C.H. Sieburgh, Tertium datur. De niet toegelaten derde in het burgerlijk recht (oratie Nijmegen), Deventer: Kluwer 2004, die stelt dat bij de beoordeling of een overeenkomst geldig is, zowel de ongeldigheid als de gevolgen ervan in aanmerking moeten worden genomen.

6. C.M.D.S. Pavillon verricht veel, ook empirisch, onderzoek naar de 'doeltreffend, evenredig en afschrikwekkend'-toets, getuige haar oratie (5 maart 2019) en het door haar georganiseerde symposium 'Sancties in het consumentenrecht, effectief, proportioneel én afschrikwekkend' (6 september 2019) alsmede C.M.D.S. Pavillon, Private Enforcement As a Deterrence Tool: A Blind Spot in the Omnibus-Directive, University of Groningen Faculty of Law Research Paper nr. 30/2019, https:// ssrn.com/abstract $=3418907$.

7. Zie voor een overzicht D.W.F. Verkade, Oneerlijke handelspraktijken jegens consumenten (Mon. BW, nr. B49a), Deventer: Wolters Kluwer 2016, nr. 73a (schadevergoeding), nrs. 75-80 (collectieve handhaving), nr. 74 (concurrenten) en nrs. 81-87 (administratieve handhaving door de Autoriteit Consument \& Markt en anderen), alsmede W.H. van Boom, Oneerlijke handelspraktijk is onrechtmatige daad. Maar wat schieten we daar mee op?, NTBR 2008, afl. 3, p. 125. 
sancties niet de 'doeltreffend, evenredig en afschrikwekkend'toets doorstaan, het hele arsenaal aan sancties die toets wel doorstaat. De beantwoording van de vraag naar de gevolgen van vernietiging van overeenkomsten bij prijspersonalisatie is daarnaast interessant omdat bij prijspersonalisatie het product doorgaans geen gebreken vertoont (en dus conform is), terwijl bij vernietiging in andere gevallen vaak ook sprake is van nonconformiteit. ${ }^{8}$ De beantwoording van deze vraag is dus ook relevant voor andersoortige gevallen van vernietiging van overeenkomsten bij conforme producten.

Ik zal de hiervoor opgeworpen vraag als volgt behandelen. Allereerst geef ik een kort overzicht van het consumentenrecht voor zover relevant voor prijspersonalisatie (par. 2). Vervolgens analyseer ik twee mogelijke gevolgen van vernietiging tegen de achtergrond van de hiervoor vermelde 'doeltreffend, evenredig en afschrikwekkend'-toets: (1) laat de consument het product teruggeven in ruil voor de betaalde prijs minus een vergoeding voor het gebruik van dat product (door de hele overeenkomst te vernietigen en vervolgens de gevolgen te verzachten; par. 3 ), of (2) verlaag de prijs (door gedeeltelijke vernietiging of volledige vernietiging met conversie; par. 4). Daarbij laat ik buiten beschouwing de in België aanwezige mogelijkheid de leverancier te verplichten de koopprijs terug te betalen aan de consument én de consument het product te laten houden. Dit doe ik omdat wij in Nederland die sanctie niet kennen, en die sanctie naar mijn mening niet evenredig is, maar ook niet doeltreffend of afschrikwekkend. ${ }^{?}$

\section{Consumentenrechtwetgeving}

Hoewel dit artikel veronderstelt dat een overeenkomst tot stand gekomen onder invloed van prijspersonalisatie kan worden vernietigd, is het toch goed om, bij wijze van inleiding en om de relevantie van het onderwerp te rechtvaardigen, kort uiteen te zetten op welke wijze prijspersonalisatie in strijd kan zijn met Nederlandse wetgeving ter uitvoering van EU-consumentenrechtwetgeving. ${ }^{10}$

Het nieuwste voorstel van het Europees Parlement voor een EU-richtlijn voor een betere handhaving en modernisering van de regels voor consumentenbescherming ${ }^{11}$ beoogt de vol-

8. Zie bijv. HR 14 november 2008, ECLI:NL:HR:2008:BF0407, NJ 2008/588 (Van Dalfsen/Gemeente Kampen).

9. Zie voor een uitgebreidere analyse van art. VI.38, VI.94 onder $1^{\circ}$ en VI.99 Wetboek van economisch recht De Graaf 2019, onder verwijzing naar o.a. P.G.F.A. Geerts, H.B. Krans, R. Steennot \& A.J. Verheij, Oneerlijke handelspraktijken: praktijkervaringen in België met de sanctie van artikel 4 WMPC, Den Haag: Boom Juridische uitgevers 2011, p. 72-77.

10. Zie in het algemeen V. Mak, Gedachten bij een 'gepersonaliseerd' consumentenrecht, TvC 2018, afl. 6, p. 274-276

11. Wetgevingsresolutie van het Europees Parlement van 17 april 2019 over het voorstel voor een richtlijn van het Europees Parlement en de Raad tot wijziging van Richtlijn 93/13/EEG van de Raad van 5 april 1993 Richtlijn 98/6/EG van het Europees Parlement en de Raad, Richtlijn 2005/29/EG van het Europees Parlement en de Raad en Richtlijn 2011/83/EU van het Europees Parlement en de Raad wat betreft betere handhaving en modernisering van de regels voor consumentenbescherming in de EU $(\operatorname{COM}(2018) 0185$ - C8-0143/2018 2018/0090(COD)). gende twee aanvullingen op de bestaande richtlijn consumentenrechten $2011 / 83^{12}$ met betrekking tot prijspersonalisatie:

1. 'Handelaren kunnen de prijs van hun aanbiedingen personaliseren voor specifieke consumenten of specifieke categorieën consumenten aan de hand van geautomatiseerde besluitvorming en profilering van consumentengedrag, waarmee zij de koopkracht van de consument kunnen inschatten. Consumenten moeten duidelijk worden geïnformeerd wanneer de prijs die zij te zien krijgen, is gepersonaliseerd aan de hand van een geautomatiseerde beslissing, zodat zij in hun besluitvorming rekening kunnen houden met de potentiële risico's. Derhalve dient aan Richtlijn 2011/83/EU een specifieke [sic] informatievereiste te worden toegevoegd op grond waarvan de consument in kennis moet worden gesteld wanneer de prijs is gepersonaliseerd aan de hand van geautomatiseerde besluitvorming. Deze [sic] informatievereiste moet niet gelden voor technieken als "dynamische" en "realtime" prijsbepaling, waarbij de prijs zeer flexibel en snel wordt veranderd naar aanleiding van de vraag op de markt, maar geen sprake is van personalisering op basis van geautomatiseerde besluitvorming.' (overweging 45)

2. 'Voordat de consument door een overeenkomst op afstand of een buiten verkoopruimten gesloten overeenkomst, dan wel een daarmee overeenstemmend aanbod daartoe is gebonden, verstrekt de handelaar de consument op duidelijke en begrijpelijke wijze de volgende informatie:

(e bis) indien van toepassing, dat de prijs is gepersonaliseerd op basis van geautomatiseerde besluitvorming'. (art. 6 lid 1 onder e bis)

Uit deze aanvullingen kan worden afgeleid dat vanuit het perspectief van EU-consumentenrechtwetgeving prijspersonalisatie zal worden toegestaan als de consument hierover wordt geïnformeerd. Anders zou het richtlijnvoorstel prijspersonalisatie geheel of gedeeltelijk hebben verboden. Het richtlijnvoorstel is echter nog niet vastgesteld en zodra dat het geval is, hebben de lidstaten 24 maanden om het om te zetten in nationale wetgeving, reden waarom ik me nu concentreer op bestaande wetgeving.

Bestaande wetgeving bevat geen specifieke regels over prijspersonalisatie, maar 'slechts' (1) algemene informatieplichten met betrekking tot de prijs en (2) algemene regels met betrekking tot oneerlijke handelspraktijken. Er zijn twee voorbeelden van algemene informatieplichten met betrekking tot de prijs die misschien kunnen worden toegepast op prijspersonalisatie. Ten eerste acht Neppelenbroek ${ }^{13}$ verdedigbaar dat op degene die een dienst van de informatiemaatschappij verleent een

12. Richtlijn 2011/83/EU van het Europees Parlement en de Raad van 25 oktober 2011 betreffende consumentenrechten, tot wijziging van Richtlijn 93/13/EEG van de Raad en van Richtlijn 1999/44/EG van het Europees Parlement en de Raad en tot intrekking van Richtlijn 85/577/ EEG en van Richtlijn 97/7/EG van het Europees Parlement en de Raad.

13. E.D.C. Neppelenbroek, Wat de gek ervoor geeft. Big Data en de bescherming van de contractuele wederpartij bij prijsdiscriminatie, WPNR 2017/7110, p. 447-448. 
informatieplicht rust voor het gebruik van big data voor prijsdiscriminatie op grond van art. 3:15d lid 3 jo. lid 2 Burgerlijk Wetboek (BW) (art. 5 lid 2 richtlijn elektronische handel $\left.2000 / 31^{14}\right)$. Hij vindt dat bij niet-naleving van die informatieplicht de consument die dienstverlener kan aanspreken uit hoofde van onrechtmatige daad. Ten tweede meent Neppelenbroek dat de handelaar op grond van art. 6:230m lid 1 onder e BW (art. 6 lid 1 onder e richtlijn consumentenrechten) niet gehouden is aan te geven hoe de prijs tot stand is gekomen, maar de consument wel moet informeren dat de prijs mede is gevormd door analyse van het consumentengedrag. ${ }^{15}$ Als met hem kan worden aangenomen dat de handelaar de informatieplicht van art. 6:230m BW schendt, dan kan de consument de overeenkomst volgens hem vernietigen als die onder invloed daarvan tot stand is gekomen. Ook Schaub en Tigelaar hebben zich eerder in algemene zin uitgesproken voor een vernietigingssanctie bij schending van informatieplichten voortvloeiend uit art. 6:230 $\mathrm{mW} .^{16}$

Door Bulten is echter aangevoerd - en ik ben geneigd het met haar eens te zijn - dat het te ver voert om informatieplichten met betrekking tot prijspersonalisatie af te leiden uit algemene verplichtingen die op leveranciers rusten om consumenten te informeren over de prijs van het product. ${ }^{17} \mathrm{Bij}$ prijspersonalisatie wordt de consument immers wel geïnformeerd over de prijs. In zoverre wordt er voldaan aan informatieplichten op grond waarvan de prijs moet worden vermeld. Om die reden ligt het meer voor de hand de vraag te stellen of het niet informeren van de consument over prijspersonalisatie een oneerlijke handelspraktijk is in de zin van de richtlijn oneerlijke handelspraktijken 2005/29 (hierna: richtlijn OHP). Voordat ik deze vraag beantwoord, merk ik in algemene zin op dat de richtlijn OHP een maximumharmonisatierichtlijn is (art. 4

14. Richtlijn 2000/31/EG van het Europees Parlement en de Raad van 8 juni 2000 betreffende bepaalde juridische aspecten van de diensten van de informatiemaatschappij, met name de elektronische handel, in de interne markt.

15. Neppelenbroek 2017, p. 449 en voetnoot 33.

16. M.Y. Schaub, Een stevig web van regels voor het sluiten van elektronische overeenkomsten, SEW 2014, afl. 10, p. 445; L.B.A. Tigelaar, Sancties op schending van informatieplichten uit de Richtlijn consumentenrechten, TvC 2013, afl. 4, p. 158. Volledigheidshalve zij opgemerkt dat Schaub, Tigelaar en Neppelenbroek verschillende opvattingen hebben over stelplicht en bewijslast met betrekking tot het causale verband tussen het schenden van de informatieplicht en het aangaan van de overeenkomst. Zie verder art. 6:230i lid 1 jo. art. 3:40 lid 2 BW.

17. M.E. Bulten, Online prijspersonalisatie in het Nederlandse consumentenrecht, TvC 2018, afl. 4, p. 186-187. richtlijn OHP), ${ }^{18}$ prijspersonalisatie niet wordt vermeld als een handelspraktijk die onder alle omstandigheden wordt beschouwd als oneerlijk in de zin van art. 6:193g BW (art. 5 lid 5 jo. bijlage I richtlijn OHP) en het onwaarschijnlijk is dat prijspersonalisatie wordt beschouwd als agressief in de zin van art. 6:193h- 193i BW (art. 8 en 9 richtlijn OHP) of misleidend in de zin van art. 6:193c BW (art. 6 richtlijn OHP).

Als prijspersonalisatie überhaupt als oneerlijke handelspraktijk kan worden beschouwd, dan zal dat het geval zijn als een leverancier een consument niet informeert dat prijspersonalisatie wordt gebruikt. Een dergelijk nalaten kan mogelijkerwijs worden gekwalificeerd als een oneerlijke handelspraktijk omdat het een misleidende omissie is in de zin van art. 6:193d BW (art. 5 lid 4 onder a jo. art. 7 richtlijn OHP), of in algemene zin een oneerlijke handelspraktijk in de zin van art. 6:193b lid 2 BW (art. 5 lid 2 richtlijn OHP). In beide gevallen moet aan een causaliteitseis worden voldaan en een materialiteitsdrempel worden genomen. De causaliteitseis komt er in het geval van een misleidende omissie op neer dat 'essentiële informatie' moet zijn weggelaten, 'waardoor de gemiddelde consument een besluit over een transactie neemt of kan nemen, dat hij anders niet had genomen' in de zin van art. 6:193d lid 1 en 2 BW (art. 7 lid 1 en 2 richtlijn OHP). De materialiteitsdrempel betekent dat in het geval van een meer algemene oneerlijke handelspraktijk, de handelspraktijk alleen als oneerlijk wordt beschouwd als het vermogen van de gemiddelde consument om een geïnformeerd besluit te nemen merkbaar is beperkt of kan worden beperkt (...) waardoor de gemiddelde consument een besluit over een overeenkomst neemt of kan nemen, dat hij anders niet had genomen' in de zin van art. 6:193b lid 2 BW (art. 5 lid 2 jo. art. 2 onder e richtlijn OHP). ${ }^{19}$ Afhankelijk van de feiten en omstandigheden van het geval kan daar dus sprake van zijn bij prijspersonalisatie.

Hoe het ook zij, in het vervolg zal ik ervan uitgaan dat de consument niet is geïnformeerd over prijspersonalisatie, dat

18. HvJ EG 23 april 2009, ECLI:EU:C:2009:244, NJ 2009/373 (VTB$\mathrm{VAB} /$ Total Belgium \& Galatea/Sanoma), r.o. 51-53: 'Nu dit vaststaat, dient er om te beginnen aan te worden herinnerd dat de richtlijn overeenkomstig de punten 5 en 6 van de considerans en artikel 1 ervan tot doel heeft, uniforme regels voor oneerlijke handelspraktijken van ondernemingen jegens consumenten vast te stellen, teneinde tot de goede werking van de interne markt bij te dragen en een hoog niveau van consumentenbescherming tot stand te brengen. (...) De richtlijn brengt aldus een volledige harmonisatie van deze regels op communautair niveau tot stand. Zoals artikel 4 van de richtlijn uitdrukkelijk bepaalt kunnen de lidstaten dus, anders dan VTB en de Franse regering beweren, geen strengere maatregelen vaststellen dan die welke in de richtlijn zijn neergelegd, ook niet om een hoger niveau van consumentenbescherming tot stand te brengen.'

19. In overweging 6 van de richtlijn OHP wordt het causaliteitsvereiste als volgt nader ingevuld: 'Deze richtlijn is evenmin van invloed op algemeen aanvaarde reclame- en marketingpraktijken zoals het op legitieme wijze in de markt zetten van een product ("product placement"), merkdifferentiatie en het aanbieden van premies, die het beeld dat de consument van het product heeft en zijn gedrag op wettige wijze kunnen beïnvloeden zonder daarom het vermogen van de consument om een geïnformeerd besluit te nemen, te beperken.' 
dit voor de gemiddelde consument een oneerlijke handelspraktijk is, dat aan alle relevante vereisten (waaronder causaliteit en materialiteit) is voldaan, en dat de consument op grond daarvan de overeenkomst vernietigt op grond van art. 6:193j lid $3 \mathrm{BW} .{ }^{20}$ Het gaat me in dit artikel immers (vrijwel) uitsluitend over de gevolgen van de vernietiging. En omdat het mij alleen daarom gaat, zal ik de voorgaande lange formulering omwille van beknoptheid samenvatten door te vermelden dat de consument een overeenkomst vernietigt vanwege prijspersonalisatie. Degenen die meer zien in het vernietigen van een overeenkomst tot stand gekomen onder invloed van prijspersonalisatie op grond van de huidige (of anticiperend op de toekomstige) richtlijn consumentenrechten, kunnen dit artikel mutatis mutandis op hun lezing toepassen. ${ }^{21}$

\section{Retourneer de zaak, krijg geld terug en betaal een gebruiksvergoeding (volledige vernietiging met beperking van de gevolgen)}

Een van de manieren om om te gaan met de gevolgen van vernietiging van een overeenkomst gesloten onder invloed van prijspersonalisatie is om uit te gaan van volledige vernietiging en vervolgens de gevolgen van een dergelijke vernietiging te verzachten. Dat kan door de consument een vergoeding te laten betalen voor de periode dat hij de zaak heeft gebruikt. Ik zal deze mogelijkheid hieronder bespreken en zodoende beoordelen in hoeverre ons vernietigingsrecht voldoende is uitgerust om om te gaan met situaties waarin de zaken conform zijn, zoals bij prijspersonalisatie. Als de overeenkomst door de consument wordt vernietigd, wordt de hele overeenkomst met terugwerkende kracht getroffen en geacht nooit te hebben bestaan (art. 3:53 BW), en kunnen partijen hetgeen is gegeven of gepresteerd als onverschuldigd betaald terugvorderen (art. 6:203 BW). Zoals ik hieronder zal aantonen, verschillen deze gevolgen al naar gelang een zaak of dienst werd geleverd.

\subsection{Zaken en ongerechtvaardigde verrijking}

$\mathrm{Als}$ een overeenkomst met betrekking tot een verkochte en afgeleverde zaak (bijvoorbeeld een auto) wordt vernietigd vanwege prijspersonalisatie, dan moet de consument die zaak aan de leverancier teruggeven en de leverancier de koopprijs aan de consument terugbetalen. Is de consument vervolgens verplicht een vergoeding te betalen voor het gebruik van de zaak voorafgaand aan de vernietiging, dat wil zeggen een gebruiksvergoeding? Gezien het feit dat de vraag of een gebruiksvergoeding

20. Dit vernietigingsrecht is overigens niet geïntroduceerd bij de inwerkingtreding van de Nederlandse wet ter implementatie van de richtlijn OHP op 15 oktober 2008 (Stb. 2008, 397 en 398), maar toen de Nederlandse wet ter implementatie van de richtlijn consumentenrechten in werking trad op 13 juni 2014, en wel als gevolg van het aannemen van een motie van een Kamerlid (Stb. 2014, 140). Zie voor de redenen waarom L.B.A. Tigelaar, Sanctionering van informatieplichten uit de Richtlijn consumentenrechten (diss. Groningen), Zutphen: Uitgeverij Paris 2017, nrs. 308-312 en 407-414.

21. Art. 24 richtlijn consumentenrechten vereist, net als art. 13 richtlijn OHP, dat de sancties gesteld op inbreuken op nationale wetgeving ter implementatie van die richtlijn 'doeltreffend, evenredig en afschrik[wek]kend' zijn. moet worden betaald in de rechtspraak en de literatuur vooral aan de orde is geweest bij gevallen van ontbinding van een koopovereenkomst als gevolg van non-conformiteit, zal ik eerst deze andere, maar toch soortgelijke situatie analyseren. Met behulp van de aldus opgedane kennis kan vervolgens de moeilijkere situatie van vernietiging worden behandeld.

In het Quelle-arrest ${ }^{22}$ oordeelde het Hof van Justitie dat bij vervanging van een non-conforme zaak geen vergoeding mag worden geëist voor het gebruik van die zaak tot aan de vervanging ervan, omdat art. 3 van de verkooprichtlijn 1999/4423 zich daartegen verzet. Belangrijker voor dit artikel is echter dat het Hof in r.o. 38 en 39 duidelijk maakte dat deze regel niet geldt voor de ontbinding van een overeenkomst vanwege nonconformiteit. Daarbij wees het Hof op overweging 15 van de verkooprichtlijn, op grond waarvan het de lidstaten vrijstaat te bepalen 'dat elke terugbetaling aan de consument kan worden verminderd teneinde rekening te houden met het gebruik dat de consument van het goed heeft gehad sedert het hem is afgeleverd (...)', en deze gebruiksvergoeding meteen in verband werd gebracht met ontbinding: 'dat de gedetailleerde regeling betreffende de wijze waarop tot de ontbinding van de overeenkomst wordt gekomen, kan worden vastgelegd in het nationale recht'. Uit de nieuwe verkooprichtlijn 2019/771 blijkt het nog duidelijker. ${ }^{24}$ Art. 14 lid 4 van die richtlijn bepaalt: 'De consument hoeft niet te betalen voor normaal gebruik van de vervangen goederen in de aan de vervanging voorafgaande periode', en uit art. 3 lid 7 blijkt dat deze regel niet van toepassing is op de gevolgen van ontbinding:

'Deze richtlijn doet geen afbreuk aan het recht van de lidstaten om te voorzien in regels betreffende aspecten van het algemene overeenkomstenrecht, zoals regels inzake de totstandkoming, de geldigheid, de nietigheid of de gevolgen van overeenkomsten, met inbegrip van de gevolgen van de ontbinding van een overeenkomst voor zover zij niet in deze richtlijn worden geregeld, of het recht op schadevergoeding.'

In overweging 60 wordt zelfs overwogen dat het de lidstaten vrijstaat de gevolgen van waardedaling te regelen:

'Deze richtlijn mag geen afbreuk doen aan het recht van de lidstaten om de andere dan de in deze richtlijn neergelegde gevolgen van de ontbinding te regelen, zoals de gevolgen

22. HvJ EG 17 april 2008, ECLI:EU:C:2008:231, NJ 2008/382 (Quelle), r.o. 43.

23. Richtlijn 1999/44/EG van het Europees Parlement en de Raad van 25 mei 1999 betreffende bepaalde aspecten van de verkoop van en de garanties voor consumptiegoederen.

24. Richtlijn (EU) 2019/771 van het Europees Parlement en de Raad van 20 mei 2019 betreffende bepaalde aspecten van overeenkomsten voor de verkoop van goederen, tot wijziging van Verordening (EU) 2017/2394 en Richtlijn 2009/22/EG, en tot intrekking van Richtlijn 1999/44/EG. De lidstaten moeten de richtlijn uiterlijk op 1 juli 2021 implementeren en van toepassing laten zijn op overeenkomsten gesloten op of na 1 januari 2022 (art. 24). Richtlijn 1999/44 wordt ingetrokken met ingang van 1 januari 2022 (art. 23). 
van de waardedaling, de vernietiging of het verlies van de goederen.'

Hijma ${ }^{25}$ en $\operatorname{Loos}^{26}$ zien mogelijkheden voor een gebruiksvergoeding bij ontbinding (art. 6:265 BW) op grond van ongerechtvaardigde verrijking (art. 6:212 BW), en $\mathrm{Mak}^{27}$ daarnaast ook voor een nieuw-voor-oud-vergoeding bij herstel. Deze vergoeding uit hoofde van ongerechtvaardigde verrijking kan bestaan uit een redelijke gebruiksvergoeding (aldus Damminga), ${ }^{28}$ afschrijving (aldus Hijma) ${ }^{29}$ of de marktwaarde van het gebruik (aldus Van der Linden). ${ }^{30}$

Deze vrijheid om bij ontbinding een gebruiksvergoeding toe te kennen kan naar analogie worden toegepast om ook bij vernietiging een gebruiksvergoeding toe te kennen. Vernietiging vertoont immers gelijkenis met ontbinding, in ieder geval meer dan met vervanging. Zowel bij vernietiging als bij ontbinding is de leverancier immers verplicht de koopprijs aan de consument terug te betalen en is de overeenkomst niet langer van kracht (art. 6:53 jo. art. 6:203 BW respectievelijk art. 6:271 BW). ${ }^{31}$ En in beide gevallen vindt het recht van de consument de betreffende remedie uit te oefenen zijn oorsprong in iets dat is toe te rekenen aan de leverancier, ofwel zijn gedrag (in geval van vernietiging), ofwel de door hem geleverde zaak (in geval van ontbinding). Daarentegen is de leverancier bij vervanging niet verplicht de koopprijs aan de consument terug te betalen en blijft de overeenkomst van kracht.

Men zou op grond van de volgende redenering zelfs kunnen betogen dat er meer behoefte is een gebruiksvergoeding toe te kennen als een overeenkomst wordt vernietigd vanwege prijspersonalisatie dan wanneer een overeenkomst wordt ontbonden vanwege een non-conforme zaak. Zoals de Nederlandse wetgever heeft uitgelegd lang voor het Quelle-arrest, hoeven bij vervanging geen gebruikskosten te worden betaald omdat

25. Asser/Hijma 7-I* 2019/707, onder verwijzing naar Hof Arnhem 23 november 2004, ECLI:NL:GHARN:2004:AV1205, NJF 2006/66 (Pouw/Mans).

26. M.B.M. Loos, Consumentenkoop (Mon. BW, nr. B65b), Deventer: Wolters Kluwer 2019, nr. 37, die ook voorbeelden noemt van gevallen waarin de verkoper zijns inziens niet tot een gebruiksvergoeding gerechtigd is.

27. V. Mak, 'Kosteloze' vervanging bij non-conformiteit: is de consument een vergoeding verschuldigd voor het genoten gebruik van een gebrekkige zaak?, NtER 2009, afl. 1, p. 34-40.

28. S.R. Damminga, Ongerechtvaardigde verrijking en onverschuldigde betaling als bronnen van verbintenissen (diss. Nijmegen), Deventer: Kluwer 2014, p. 240-242.

29. In algemene zin Asser/Hijma 7-I* 2019/558. In een B2C-context zal afschrijving een lastig toepasbare waarderingsgrondslag opleveren omdat consumenten gekochte zaken niet plegen te activeren op een balans en vervolgens afschrijven.

30. T. van der Linden, Aanvullend verrijkingsrecht (diss. Leiden), Den Haag: Boom juridisch 2019, p. 159-161.

31. $\mathrm{Zij}$ het dat met betrekking tot het verleden vernietiging terugwerkende kracht heeft, waardoor de overeenkomst geacht wordt nooit te hebben bestaan (art. 3:53 BW), terwijl ontbinding geen terugwerkende kracht heeft (art. 6:269 BW). de belangen van de leverancier meestal al voldoende zijn beschermd, gezien het feit dat onder andere:

1. in de meeste gevallen de zaak slechts korte tijd is gebruikt voordat de non-conformiteit zich manifesteert;

2. gezien deze korte periode zelden aanzienlijke gebruikskosten ontstaan; en

3. het proces van vervanging in doorsneegevallen niet mag worden gecompliceerd door geschillen over gebruiksvergoedingen. ${ }^{32}$

Soortgelijke argumenten kunnen ook worden aangedragen om te betogen dat geen gebruiksvergoeding verschuldigd is als een overeenkomst wordt ontbonden terwijl de zaak alleen voor korte tijd is gebruikt. Of, anders gezegd: als de zaak voor langere tijd is gebruikt, is er ruimte om bij ontbinding wel een gebruiksvergoeding te laten betalen. Bij prijspersonalisatie is de kans echter groot dat het veel langer duurt voordat de prijspersonalisatie aan het licht komt dan wanneer non-conformiteit zich manifesteert. In dat geval is de zaak veel langer gebruikt en zijn er waarschijnlijk hogere gebruikskosten ontstaan. Als een overeenkomst vanwege prijspersonalisatie wordt vernietigd, is er dus meer reden om rekening te houden met de belangen van de leverancier door de consument te laten betalen voor het gebruik. Daarvoor is eens te meer reden omdat in geval van prijspersonalisatie er niets mis is met de geleverde zaak, terwijl in de meeste gevallen van vernietiging het vernietigingsrecht zoals gezegd niet alleen ontstaat door het gedrag van de leverancier, maar de gekochte zaak ook nonconform is. Neem bijvoorbeeld een verkoper die nalaat een consument te informeren dat met de kilometerstand van de auto is geknoeid, of dat de bodem sterk is vervuild. Aan de andere kant zou kunnen worden betoogd dat met deze belangen van de leverancier geen rekening moet worden gehouden. Als de leverancier zich in het geheim schuldig maakt aan een oneerlijke handelspraktijk, dan moet hij maar op de blaren zitten en komt hem geen gebruiksvergoeding toe. Hoe het ook zij, de hiervoor besproken parlementaire geschiedenis biedt naar mijn idee eerder meer dan minder aanknopingspunten om bij prijspersonalisatie de leverancier een gebruiksvergoeding toe te kennen.

Ook kan een vergelijking worden gemaakt met de waardevermindering waarvoor de consument in bepaalde gevallen aansprakelijk is als hij een overeenkomst op afstand 'ontbindt' tijdens de bedenktijd en dus niet op grond van non-conformiteit: zie art. 6:230o lid 1 jo. art. 6:230s lid 3 BW (implementatie van art. 9 lid 1 jo. art. 14 lid 2 richtlijn consumentenrechten). Dat ontbindingsrecht is ingevoerd om de consument die op afstand (meestal bij een webshop) koopt in staat te stellen de gekochte zaken te testen en inspecteren. Dat is iets dat de consument die op afstand kocht niet kon doen vóór de koop en wat hij wel had kunnen doen als hij de zaak had gekocht bij een fysieke winkel, zie overweging 37 van de richtlijn consumentenrechten. In die situaties kan de consument worden ver-

32. Parl. Gesch. Boek 7 (Inv. 3, 5 en 6), p. 136-137 (MvT) en p. 141-142 (MvA II) 
plicht 'tot het betalen van een billijke compenserende vergoeding in de situatie waarin deze het middels een overeenkomst op afstand verworven goed heeft gebruikt op een wijze die onverenigbaar is met de beginselen van burgerlijk recht, zoals die van de goede trouw of van de ongerechtvaardigde verrijking', aldus het Hof van Justitie in het Messner-arrest. ${ }^{33}$ Later werd deze regel gecodificeerd in art. 14 lid 2 richtlijn consumentenrechten en geïmplementeerd in art. 6:230s lid 3 BW. In laatstgenoemd artikel staat:

'De consument is slechts aansprakelijk voor de waardevermindering van de zaak als een behandeling van de zaak verder is gegaan dan noodzakelijk om de aard, de kenmerken en de werking daarvan vast te stellen.'

Op grond van art. 6:230s lid 6 BW (implementatie van art. 14 lid 5 richtlijn consumentenrechten) is de consument 'niet aansprakelijk noch enige kosten verschuldigd door uitoefening van zijn recht van ontbinding, onverminderd het bepaalde in lid 3 (...)' en is de waardeverminderingsaanspraak dus exclusief van aard.

Art. 6:230s lid 3 BW bepaalt ook dat de consument niet aansprakelijk is voor de waardevermindering als de leverancier de consument niet op de hoogte heeft gesteld van zijn ontbindingsrecht. In het verlengde daarvan zou kunnen worden betoogd dat als een leverancier een consument niet heeft geïnformeerd over prijspersonalisatie, de consument niet aansprakelijk dient te zijn voor een waardevermindering van de gekochte zaken. De richtlijn consumentenrechten noch het hiervoor al aangehaalde recente voorstel tot wijziging van die richtlijn voorziet echter in een dergelijke specifieke sanctie als informatie met betrekking tot prijspersonalisatie niet is verstrekt, en ook niet in een specifieke sanctie op grond waarvan een andersoortige vergoeding wordt ontzegd. Mede daardoor gaat de vergelijking met de richtlijn consumentenrechten mank. Die vergelijking biedt dus geen grond de leverancier enige (waardeverminderings- of gebruiks)vergoeding te ontzeggen als hij de consument niet over prijspersonalisatie heeft geïnformeerd.

Dat brengt mij tot het volgende punt. Een waardeverminderingsvergoeding is niet hetzelfde als een gebruiksvergoeding. Bij een waardeverminderingsvergoeding in geval van koop op afstand wordt gekeken naar de waarde van de geretourneerde zaak. Het toekennen van die vergoeding aan de leverancier strekt ertoe hem te compenseren voor het feit dat de geretourneerde zaak in waarde is gedaald door toedoen van de consument en de leverancier die zaak daardoor niet voor dezelfde prijs aan een andere consument kan verkopen. Bij een gebruiksvergoeding wordt daarentegen gekeken naar de

33. HvJ EG 3 september 2009, ECLI:EU:C:2009:502, NJ 2009/559 (Messner/Stefan Krüger). Dit arrest is gewezen onder de voorganger van de richtlijn consumentenrechten, de Richtlijn 97/7/EG van het Europees Parlement en de Raad van 20 mei 1997 betreffende de bescherming van de consument bij op afstand gesloten overeenkomsten. waarde die het gebruik van de geretourneerde zaak voor de consument (objectief of subjectief) heeft gehad. Niet relevant lijkt voor welk doel de leverancier de gebruiksvergoeding aanwendt. Ik laat dit punt hier verder rusten omdat, zoals gezegd, de richtlijn consumentenrechten wel voorziet in een specifiek en exclusief sanctieregime in geval van 'ontbinding' van een koop op afstand, maar niet in een zodanig regime in geval van schending van de voorgestelde verplichting de consument over prijspersonalisatie te informeren.

Hoewel dus op veel punten de vergelijking mank gaat tussen de gevolgen van vernietiging bij prijspersonalisatie en de gevolgen van 'ontbinding' bij koop op afstand, is de vergelijking wel degelijk van belang. Uit de vergelijking blijkt immers dat het Hof van Justitie in Quelle en Messner zelf maatregelen introduceerde om de effecten van sancties te verzachten door middel van ongerechtvaardigde verrijking.

Bovendien komt de consument niet met lege handen te staan door de leverancier niet te verplichten de volledige koopprijs terug te betalen en de consument te verplichten een gebruiksvergoeding te betalen. Hij kan immers schadevergoeding vorderen op grond van art. 6:193b lid 1 jo. art. 6:162 BW, dat met zoveel woorden bepaalt dat een handelaar onrechtmatig jegens een consument handelt als hij een oneerlijke handelspraktijk verricht. Vanuit het oogpunt van de consument is het instellen van een schadevergoedingsvordering echter bezwaarlijk, niet alleen vanwege hetgeen de consument moet stellen en bij voldoende gemotiveerde betwisting moet bewijzen, maar met name vanwege de verweermiddelen die de leverancier ter beschikking staan, bijvoorbeeld overeengekomen exoneraties en vermindering van schade vanwege het niet beperken van schade of eigen schuld (art. 6:101 BW).

Toegegeven, de jurisprudentie van de Hoge Raad lijkt in een andere richting te wijzen dan de richting die ik voorsta. In het Lindorff/Nazier-arrest oordeelde de Hoge Raad dat in geval van vernietiging van all-in mobiele-telefonieovereenkomsten (dat wil zeggen overeenkomsten waarbij consumenten een mobiele-telefonieabonnement hadden afgesloten met 'gratis' mobiele telefoon) de consument niet gehouden was op grond van ongerechtvaardigde verrijking een gebruiksvergoeding te betalen voor het genot dat hij van het toestel heeft gehad. ${ }^{34}$ Dit zou volgens de Hoge Raad 'onredelijk'35 zijn omdat het de consument niet effectief zou beschermen en afbreuk zou doen 'aan het vereiste dat de sanctie op schending van art. 7:61 lid 2

34. HR 12 februari 2016, ECLI:NL:HR:2016:236, NJ 2017/282 (Lindorff/ Nazier), r.o. 3.16 en Verkade 2016, nr. 71 a.

35. Redelijkheid is een van de vereisten voor het toekennen van schadevergoeding uit hoofde van ongerechtvaardigde verrijking, zie art. 6:212 lid 1 BW. 
BW doeltreffend en afschrikwekkend moet zijn (...) ${ }^{36}$ Dit oordeel is zwaar bekritiseerd door onder anderen Hijma en Pavillon, naar mijn idee terecht, omdat de door de Hoge Raad uitgesproken sanctie onevenredig is. ${ }^{37}$

Ik geloof dat de door mij voorgestane gevolgen van vernietiging - te weten het retourneren van de zaak tegen betaling van een gebruiksvergoeding - daarentegen wel evenredig zijn, omdat rekening wordt gehouden met de belangen van zowel de consument als de leverancier: die van de consument omdat hij volledig kan vernietigen en zo nodig schadevergoeding kan vorderen, die van de leverancier omdat hij op grond van ongerechtvaardigde verrijking bij vernietiging gerechtigd is tot een vergoeding voor het gebruik dat de consument van de zaak heeft gemaakt. Bovendien is het verzachten van de effecten van sancties door middel van ongerechtvaardigde verrijking een optie die het Hof van Justitie zelf naar voren bracht in Quelle en Messner, en is dit ook in overeenstemming met de huidige en nieuwe verkooprichtlijn. Ook ben ik van mening dat de voorgestelde sancties voldoende 'afschrikwekkend' zijn, zoals vereist door art. 13 richtlijn OHP. Hoewel aan de leverancier gebruikskosten kunnen worden toegekend en de ernstige gevolgen van vernietiging voor hem daardoor kunnen worden verzacht, worden de bewuste zaken nog steeds aan hem geretourneerd en moet hij ze nog een keer verkopen om een vergelijkbare winst te maken als hij zou hebben gemaakt als de overeenkomst intact zou zijn gebleven. Om de zaken voor de tweede keer te verkopen moet de leverancier ze waarschijnlijk nog een keer verpakken (en misschien zelfs herstellen), te koop aanbieden tegen een gereduceerde prijs (omdat ze zijn gebruikt) en marketing- en andere kosten maken. Het is onwaarschijnlijk dat die kosten volledig kunnen worden gerecupereerd door de gebruiksvergoeding die de consument aan hem moet betalen. Om die reden is de sanctie naar mijn mening voldoende nadelig om afschrikwekkend voor de leverancier te zijn.

Of een leverancier al dan niet recht heeft op een gebruiksvergoeding in het geval dat een overeenkomst wordt vernietigd vanwege prijspersonalisatie, hangt uiteindelijk af van de vraag of de nadruk wordt gelegd op het evenredig zijn van de sanctie, of eerder op het afschrikwekkende karakter. Alle argumenten

36. De criteria 'doeltreffend' en 'afschrikwekkend' maken onderdeel uit van het bekende trio 'doeltreffend, evenredig en afschrikkend' in art. 23 van de hier van toepassing zijnde Richtlijn 2008/48/EG van het Europees Parlement en de Raad van 23 april 2008 inzake kredietovereenkomsten voor consumenten en tot intrekking van Richtlijn 87/102/EEG van de Raad.

37. Zie bijv. Jac. Hijma in zijn NJ-noot bij HR 12 februari 2016, ECLI:NL:HR:2016:236, NJ 2017/282 (Lindorff/Nazier), nr. 19-20, Jac. Hijma, Ontwikkelingen overeenkomstenrecht (III), WPNR 2017/7166, p. 783-784 en C.M.D.S. Pavillon, Materieelrechtelijke beschouwingen naar aanleiding van de tweede gratis-mobieltjes-uitspraak van de Hoge Raad. HR 12 februari 2016, ECLI:NL:HR:2016:236, TvC 2016, afl. 5, p. 239. Zie ook N. Huppes, C.M.D.S. Pavillon \& T.L. Wildenbeest, De fabel van het gratis mobieltje, NTBR 2019, afl. 5, p. 20-32, die voor een alternatieve sanctie pleiten. afwegend vind ik om de hiervoor uiteengezette redenen dat een gebruiksvergoeding moet worden betaald.

\subsection{Diensten en gebruiksvergoeding}

Als een overeenkomst met betrekking tot diensten volledig ${ }^{38}$ wordt verricht (bijvoorbeeld een vlucht) en vervolgens wordt vernietigd vanwege prijspersonalisatie, moet de leverancier aan de consument het betaalde bedrag terugbetalen (art. 6:203 lid $2 \mathrm{BW}$ ) en heeft de leverancier ten opzichte van de consument recht op ongedaanmaking van zijn prestatie (art. 6:203 lid $3 \mathrm{BW}$ ). In tegenstelling tot gegeven zaken kunnen verrichte diensten naar hun aard niet ongedaan worden gemaakt. Om die reden bepaalt art. 6:210 lid $2 \mathrm{BW}$ :

'Sluit de aard van de prestatie uit dat zij ongedaan wordt gemaakt, dan treedt, voor zover dit redelijk is, vergoeding van de waarde van de prestatie op het ogenblik van ontvangst daarvoor in de plaats, indien de ontvanger door de prestatie is verrijkt, indien het aan hem is toe te rekenen dat de prestatie is verricht, of indien hij erin had toegestemd een tegenprestatie te verrichten.'

Een consument die een vlucht van A naar B nam en de overeenkomst vervolgens vernietigde, is duidelijk verrijkt met de vlucht. Om die reden moet hij in principe de waarde van de dienst terugbetalen, objectief vastgesteld op de marktwaarde op het moment van ontvangst en voor zover redelijk (art. 6:210 lid 2 BW). ${ }^{39}$ Er lijken twee manieren om dergelijke gebruiksvergoedingen te bepalen, die elk hun eigen voor- en nadelen hebben.

De eerste manier om de eventueel te betalen gebruiksvergoeding te bepalen, is die vast te stellen op de marktwaarde op het moment van ontvangst, dat wil zeggen de dag van de vlucht. Dat is de hoofdregel van art. 6:210 lid 2 BW. Prijsschommelingen tussen het moment van boeken en de vlucht kunnen echter in het voordeel, maar ook in het nadeel van de consument werken. De billijkheid van deze oplossing laat te wensen over, en ook de onzekerheid daarvan maakt deze optie weinig aantrekkelijk.

De tweede manier om de gebruiksvergoeding vast te stellen, is om de meer gedetailleerde juridische literatuur over de gevolgen van ontbinding vanwege een tekortkoming in de nakoming van een dienstenovereenkomst naar analogie toe te passen. De woorden 'voor zover dit redelijk is' in art. 6:210 lid 2 BW bieden daartoe de ruimte. Bij deze analoge toepassing doel ik met name op het regime van art. 6:272 BW. Dat regime makt onderscheid tussen de situatie waarin de prestaties naar behoren zijn uitgevoerd (lid 1) en de situatie waarin dit niet het geval is (lid 2). In het eerste geval komt de door de

38. Om een en ander niet nog ingewikkelder te maken, neem ik in dit artikel aan dat alle diensten volledig zijn verricht, niet gedeeltelijk.

39. Parl. Gesch. Boek 6, p. 818-819 (T.M.) en HR 5 december 2014 ECLI:NL:HR:2014:3532, NJ 2016/159 (Michielse/gemeente ReuselDe Mierden). 
consument terug te betalen waarde bijna altijd overeen met de contractprijs, terwijl in het laatste geval de waarde wordt vastgesteld op de waarde die de dienst daadwerkelijk voor de consument heeft gehad. ${ }^{40}$ Gezien het feit dat bij prijspersonalisatie de dienst volledig en naar behoren is verricht en de consument ten volle daarvan heeft geprofiteerd, zou de waarde van de vergoeding worden vastgesteld op de overeengekomen prijs. Het nettoresultaat daarvan is 0 , omdat de leverancier het ontvangen geld terugbetaalt en de consument de contractprijs betaalt. De consument zou in dat geval dus geen geld terugkrijgen.

De consument zou daartegen in kunnen brengen dat de contractprijs niet tot uitgangspunt kan worden genomen omdat die hoger lag dan de marktwaarde en dat voor hem nu juist de reden was de overeenkomst te vernietigen. Hiertegen kan worden aangevoerd dat in geval van prijspersonalisatie een algemene marktwaarde voor de geleverde dienst niet kan worden vastgesteld, omdat de marktwaarde niet per dienst, maar voor iedere individuele consument wordt bepaald. Ook leidt het bij wijze van benchmark vaststellen van de prijs van een vergelijkbare dienst (van een concurrent die geen prijspersonalisatie hanteert) al snel tot een vergelijking van appels met peren, waardoor die oplossing in de praktijk lastig uitvoerbaar zal zijn.

Dit lijkt misschien niet redelijk voor de consument, en hij zal waarschijnlijk beweren dat het enkele feit dat de dienst volledig en naar behoren is verricht van onvoldoende gewicht is om hem de facto het recht te ontnemen op te treden tegen prijspersonalisatie, en dit ook niet afschrikwekkend is voor de leverancier. Het niet toekennen aan de individuele consument van een voldoende afschrikwekkende remedie bij vernietiging betekent echter niet noodzakelijkerwijs dat het arsenaal aan beschikbare sancties niet voldoende afschrikwekkend is. Nogmaals, de consument zou schadevergoeding kunnen vorderen op grond van art. 6:193b lid 1 jo. art. 6:162 BW. Hoewel deze route vanuit het oogpunt van de consument, zoals gezegd, bezwaarlijk is vanwege de aanvullende eisen waaraan de consument moet voldoen en de extra verweermiddelen die de leverancier ten dienste staan, is dit wel een mogelijkheid waar de consument gebruik van zou kunnen maken als hij compensatie wenst.

\section{Prijsverlaging (gedeeltelijke vernietiging of volledige vernietiging met conversie)}

De vraag rijst of het niet eenvoudiger zou zijn om de overeenkomst slechts gedeeltelijk te vernietigen, in plaats van de overeenkomst volledig te vernietigen en vervolgens ongewenste gevolgen te verzachten (zowel voor de leverancier als voor de consument). Dat lijkt niet alleen minder ingewikkeld, maar beperkt ook ongewenste gevolgen, lijkt in lijn met de (gepercipieerde) belangen van de consument en wordt door Pavillon en Tigelaar in een aantal gevallen aangemerkt als 'passende

40. Asser/Sieburgh 6-III 2018/704 en Van Boom, in: GS Verbintenissenrecht, art. 6:272 BW, aant. 3 . sanctie die, gelet op het belang van de consument, de voorkeur geniet boven een algehele vernietiging. ${ }^{41}$ Vanuit dogmatisch perspectief levert deze oplossing in ons specifieke geval echter problemen op. Vernietiging op grond van oneerlijke handelspraktijken (zoals prijspersonalisatie) heeft betrekking op de hele overeenkomst (art. 6:193j lid 3 BW). Hoewel de wet anders dan bij ontbinding ${ }^{42}$ niet met zoveel woorden voorziet in partiële vernietiging, wordt op basis van de algemene regel 'wie het meerdere mag, mag ook het mindere' een gedeeltelijke kwantitatieve vernietiging aanvaard, maar een gedeeltelijke kwalitatieve vernietiging niet. ${ }^{43}$ Het is dus bijvoorbeeld wel toegestaan een overeenkomst gedeeltelijk te vernietigen met betrekking tot een deel van de geleverde zaken, waardoor de consument verplicht wordt dat deel te retourneren (bijvoorbeeld 20 van de 100 kratten appels) en de leverancier gehouden is de daarvoor verschuldigde koopprijs terug te betalen (in dit voorbeeld de koopsom van 20 kratten appels). Anderzijds is het voor de consument niet toegestaan om een gedeeltelijke vernietiging te gebruiken om een prijsverlaging (actio quanti minoris) te bewerkstelligen, waardoor de consument de volledige levering behoudt en de leverancier verplicht is een deel van de koopprijs terug te betalen. ${ }^{44}$ Of, zoals Hijma dat treffend verwoordt: 'De vernietigbaarheid biedt de dwalende koper de bevoegdheid om de overeenkomst te verlaten, maar niet de bevoegdheid om haar scheef te trekken. ${ }^{45}$ En toegepast op het onderhavige geval betekent dit dat de consument door middel van partiële vernietiging vanwege prijspersonalisatie niet de prijs voor de vlucht achteraf eenzijdig kan verlagen.

In plaats daarvan bedient het Nederlandse vernietigingsrecht zich van conversie: als een overeenkomst wordt vernietigd, treft dat de hele overeenkomst en wordt zij van rechtswege geconverteerd in een geldige overeenkomst als aangenomen kan worden dat die geldige overeenkomst zou zijn gesloten in

41. C.M.D.S. Pavillon \& L.B.A. Tigelaar, Vernietiging van de overeenkomst bij een oneerlijke handelspraktijk; een hanteerbare sanctie?, Contracteren 2018 , afl. 3 , p. 79 .

42. In geval van een tekortkoming in de nakoming is prijsverlaging met betrekking tot kwaliteit wel mogelijk door middel van gedeeltelijke ontbinding (art. 6:265 en 6:270 BW) of door een specifieke wettelijke bepaling, zoals bij non-conformiteit van de verkochte zaken in geval van een consumentenkoop, zie art. 7:22 lid 1 onder b BW en Asser/Hijma 7-I* 2019/709-717.

43. Hijma, in: GS Verbintenissenrecht, art. 6:228 BW, aant. 1.2.4.2, onder verwijzing naar Hof Arnhem 24 maart 1976, ECLI:NL:GHARN: 1976:AC5717, NJ 1978/421, waarin vernietiging werd toegestaan met betrekking tot 3040 van de 4000 kratten geleverde appels. Een rechter kan hetzelfde resultaat bereiken als zou zijn bereikt indien gedeeltelijke vernietiging zou zijn toegestaan, door art. 3:53 lid $2 \mathrm{BW}$ toe te passen en, in geval van dwaling, art. 6:230 lid 2 BW. De rechter kan dit echter alleen desgevraagd doen en dus niet ambtshalve. Om een en ander niet nog ingewikkelder te maken, laat ik dit verder onbesproken.

44. Asser/Sieburgh 6-III 2018/698, De Loos-Wijker, in: GS Vermogensrecht, art. 3:41, aant. 5.1.4.1; Jac. Hijma, Nietigheid en vernietigbaarheid van rechtshandelingen (diss. Leiden), Deventer: Kluwer 1988, p. 287-294; M.E.M.G. Peletier, Rechterlijke vrijheid en partij-autonomie. Over de toepassing van discretionaire wijzigingsbevoegdheden in het contractenrecht (diss. Amsterdam VU), Den Haag: Boom Juridische uitgevers 1999 , p. 30-36.

45. Jac. Hijma, Koopprijsvermindering, WPNR 2018/7202, p. 568. 
plaats van de ongeldige vanwege haar ongeldigheid (art. 3:42 $\mathrm{BW}$ ). Om die reden moet, wat prijspersonalisatiezaken betreft, de vraag worden beantwoord of partijen een andere overeenkomst zonder prijspersonalisatie zouden hebben gesloten als ze de overeenkomst met prijspersonalisatie niet hadden gesloten vanwege haar ongeldigheid, en wat de inhoud van die andere overeenkomst zou zijn geweest.

Hier wreekt zich het Nederlandse systeem. Als de leverancier in staat is te bewijzen dat hij geen overeenkomst zonder prijspersonalisatie zou hebben gesloten als hij van de ongeldigheid ervan zou hebben geweten, is hij in staat te voorkomen dat de vernietigde overeenkomst geconverteerd wordt in een geldige. In plaats daarvan zou de overeenkomst in haar geheel worden vernietigd en de gevolgen verzacht (voor de leverancier) op de wijze zoals hierboven uiteengezet in paragraaf 3 , dat wil zeggen door de consument een gebruiksvergoeding te laten betalen. Dat de leverancier dat kan bewijzen, is niet zo onwaarschijnlijk als op het eerste gezicht wellicht lijkt. Als de hele prijsstelling is gebaseerd op prijspersonalisatie, zou cherrypicking de prijsstelling ernstig ondermijnen en tot verliesgevende contracten en uiteindelijk faillissement kunnen leiden. En dat is precies de reden waarom, vanuit leveranciersperspectief, het niet moet worden toegestaan een prijsverlaging te bewerkstelligen door middel van conversie van een vernietigde overeenkomst. Laat me dit met een voorbeeld uitleggen. Als de prijs van een product zonder prijspersonalisatie normaal gesproken 110 zou zijn (bestaande uit 50 vaste kosten per maand, 50 variabele kosten voor elke verkoop en een winstmarge van 10\%), dan kan de leverancier prijspersonalisatie gebruiken om een product in de ene maand voor 130 te verkopen aan een consument en in de andere maand voor 90 aan een andere consument. ${ }^{46} \mathrm{Als}$ de consument aan wie het product is verkocht voor 130 de overeenkomst vernietigt, maar betoogt dat de vernietigde overeenkomst kan blijven bestaan voor zover hij 110 betaalt, kan de leverancier daar met succes tegen inbrengen dat hij niet het betreffende product aan de betreffende consument zou hebben verkocht voor 110. In een dergelijk geval zou hij immers niet in staat zijn geweest om de verliesgevende verkoop voor 90 te compenseren met de winstgevende verkoop voor 130. Dan zou de leverancier veel liever de verkoop voor 130 geheel vernietigd zien en het product plus

46. Ervan uitgaande dat elke consument het maximale bedrag betaalt dat hij bereid is te betalen, maar niet meer dan de door de leverancier vastgestelde prijs, zou gebruikmaking van prijspersonalisatie (en het verkopen van een product aan een consument voor 130 en aan een andere consument voor 90) voor de leverancier voordeliger zijn dan het niet gebruiken van prijspersonalisatie (en proberen beide producten te verkopen voor 110). In het eerste geval (met prijspersonalisatie) zou hij immers twee producten in twee maanden verkopen (een voor 130 en een ander voor 90) en een winst maken van 20 (omzet van 130 minus kosten van $50+50$ voor de eerste verkoop in de eerste maand vermeerderd met omzet van 90 minus kosten van $50+50$ voor de tweede verkoop in de tweede maand). In het laatste geval (zonder prijspersonalisatie) zou hij slechts één product verkopen voor 110 (omdat de tweede consument alleen bereid is om te kopen tegen een maximale prijs van 90) en dus een verlies van 40 maken (omzet van 110 minus kosten van 50 (vast) + 50 (variabel) in de eerste maand en kosten van 50 (vast) in de tweede maand), dit alles ervan uitgaande dat elk product op bestelling wordt gemaakt. gebruiksvergoeding terugontvangen, zodat hij nog een kans heeft dat product voor 130 aan een andere consument te verkopen (mogelijkerwijs na reparatie van het product met de door de consument betaalde gebruiksvergoeding). De leverancier zou, met andere woorden, niet een nieuwe overeenkomst hebben gesloten als hij van de ongeldigheid van de oude zou hebben geweten. Dat betekent dat de vernietigde overeenkomst niet kan worden geconverteerd in een geldige en het bij volledige vernietiging met voor de leverancier verzachtende gevolgen blijft, zoals uiteengezet in paragraaf 3 .

De consument op die manier tot een volledige vernietiging dwingen is wellicht ook niet in zijn belang. Aangezien prijspersonalisatie erop is gericht dat een consument voor een product de maximale prijs betaalt die hij bereid is daarvoor te betalen, kan worden aangenomen dat die ene consument inderdaad bereid was die maximumprijs van 130 te betalen en die prijs vervolgens betaalde. In dat geval kan de consument er de voorkeur aan geven de hele overeenkomst intact te laten als om de hiervoor omschreven redenen geen prijsverlaging tot $110 \mathrm{kan}$ worden toegekend op basis van vernietiging en conversie. Het alternatief om de hele overeenkomst vernietigd te laten, het product te retourneren en een gebruiksvergoeding daarvoor te betalen kan voor hem veel nadeliger uitpakken. Van Schaick waarschuwde eerder in een ander verband voor dit soort onbedoelde consequenties. ${ }^{47}$

Als de consument die op zoek is naar een prijsverlaging zou moeten worden beschermd tegen een volledige vernietiging met voor hem onbedoelde gevolgen, zou wellicht het Santander-arrest creatief kunnen worden toegepast. Daarin oordeelde het Hof van Justitie dat 'de nationale rechter de mogelijkheid heeft om een oneerlijk beding te vervangen door een nationale bepaling van aanvullend recht, maar uit de rechtspraak van het Hof volgt dat deze mogelijkheid beperkt is tot gevallen waarin door de nietigheid van dat beding de rechter verplicht zou zijn om de overeenkomst in haar geheel te vernietigen en de consument daardoor geconfronteerd zou worden met zodanige gevolgen dat hij in zijn belangen zou worden geschaad'. ${ }^{48}$ Weliswaar is het arrest beperkt tot de omstandigheden van dat individuele geval, maar wellicht kan daaruit een meer algemene regel worden afgeleid: een overeenkomst geheel of gedeeltelijk vernietigen mag er niet toe leiden dat de consument in een situatie komt te verkeren die erger is dan de situatie waarin hij zou hebben verkeerd als de overeenkomst niet geheel of gedeeltelijk zou zijn vernietigd.

47. Zie ook A.C. van Schaick, Partiële vernietigbaarheid, NTBR 2018, afl. 7, p. 196-203, die erop wijst dat een volledige vernietiging tegen zijn wil aan de consument kan worden opgelegd, en pleit voor het toestaan van een meer direct recht op gedeeltelijke vernietiging om te voorkomen dat dat risico zich materialiseert.

48. HvJ EU 7 augustus 2018, ECLI:EU:C:2018:643, RvdW 2018/1260 (Banco Santander/Demba \& Bonet en Escobedo Cortés/Banco de Sabadell), r.o. 74, ten vervolge op o.a. HvJ EU 30 april 2014, ECLI:EU:C: 2014:282, NJ 2014/355 (Kásler/Jelzálogbank). 
Dit leidt tot allerlei interessante procesrechtelijke vragen. Die vragen spitsen zich toe op wat een rechter in zo'n geval kan of zelfs moet. Ten eerste, moet of kan hij elke partij de gelegenheid geven te reageren op de te verwachten gevolgen van volledige vernietiging, of mag dit instrument alleen worden gebruikt in die gevallen waarin de consument niet om vernietiging heeft verzocht, maar de rechter ambtshalve wil vernietigen? ${ }^{49}$ En, voordat hij dit doet, moet of kan hij partijen de gelegenheid bieden zich daarover uit te laten om partijen te beschermen tegen verrassingsbeslissingen? Ten tweede, moet of kan hij de vordering tot vernietiging zo interpreteren dat deze beperkt is tot de situatie dat een prijsverlaging kan worden bereikt, en als dit niet dat effect heeft de vordering afwijzen? Ten derde, moet of kan hij ambtshalve de rechtsgronden aanvullen in dier voege dat de gevorderde vernietiging voorwaardelijk is ten aanzien van het bereiken van een prijsverlaging (art. 25 Wetboek van Burgerlijke Rechtsvordering)? Het beantwoorden van deze vragen valt buiten het bestek van dit artikel.

Hoe het ook zij, als de hiervoor omschreven creatieve toepassing van het Santander-arrest gebruikt zou kunnen worden en die procesrechtelijke hindernissen genomen kunnen worden in het geval een consument er niet in slaagt een prijsverlaging door middel van vernietiging te bewerkstelligen, dan zou een rechter alsnog kunnen oordelen dat de overeenkomst intact blijft.

Verder lijkt het EU-consumentenrecht een alles-of-nietssanctie voor te staan en zich uit te spreken tegen discretionaire bevoegdheden die rechters de mogelijkheid bieden (oneerlijke) bedingen te converteren of de gevolgen daarvan te beperken. Een goed voorbeeld hiervan is de Banesto-zaak, waarin het Hof van Justitie oordeelde dat als een beding vernietigd wordt omdat het oneerlijk is in de zin van de richtlijn oneerlijke bedingen $93 / 13,{ }^{50}$ de rechter geen gebruik mag maken van nationale wetgeving waarmee hij 'de betrokken overeenkomst kan aanvullen door de inhoud van dat beding te herzien (...)', omdat die 'bevoegdheid (...) ertoe [zou] bijdragen dat [de] voor handelaars afschrikkende werking die uitgaat van een loutere niet-toepassing van dergelijke oneerlijke bedingen ten aanzien van de consument wordt uitgeschakeld (...) aangezien deze handelaars in de verleiding zouden blijven om die bedingen te gebruiken in de wetenschap dat ook al mochten deze ongeldig worden verklaard, de overeenkomst niettemin voor zover noodzakelijk door de nationale rechter zou kunnen worden aangevuld en het belang van die handelaars dus gediend zou zijn'. ${ }^{51}$ Interessant is dat door zo'n alles-of-niets- benadering de consument om de hiervoor omschreven redenen in zijn eigen zwaard dreigt te vallen.

\section{Conclusie}

Op basis van het voorgaande concludeer ik het volgende ten aanzien van overeenkomsten die, zoals ik aannam, tot stand zijn gekomen onder invloed van een als oneerlijke handelspraktijk aangemerkte prijspersonalisatie en om die reden kunnen worden vernietigd. Het is naar mijn idee niet toegestaan of haalbaar een zodanige overeenkomst geheel of gedeeltelijk te vernietigen en vervolgens te converteren in een wel geldige overeenkomst (zie par. 4). Door dit te doen zou de leverancier worden gedwongen tot een overeenkomst die hij niet zou hebben gesloten als er geen prijspersonalisatie zou zijn geweest, tegen betaling van een prijs die een rechter moeilijk kan bepalen (door de manier waarop prijspersonalisatie werkt) en die in strijd met EU-consumentenrechtjurisprudentie afbreuk doet aan de effectiviteit van de vernietiging. Wat volgens mij zou moeten gebeuren, is dat als de consument de overeenkomst vernietigt, hij de koopprijs terugkrijgt in ruil voor het retourneren van de zaken en het betalen van een gebruiksvergoeding in het geval de gekochte zaken conform zijn, terwijl alles bij het oude blijft in het geval diensten volledig en correct zijn verricht (zie par. 3). Toegegeven, sommige van de voorgestelde gevolgen van vernietiging zijn misschien niet altijd zeer afschrikwekkend. Ik geloof echter dat ze evenredig zijn en dat elk gebrek aan afschrikwekkendheid kan worden gecompenseerd met andere sancties, zoals schadevergoedingsacties, collectieve acties en administratieve sancties.

49. Vgl. o.a. HR 13 september 2013, ECLI:NL:HR:2013:691, NJ 2014/274 (Heesakkers/Voets), r.o. 3.9.1-3.9.3.

50. Richtlijn 93/13/EEG van de Raad van 5 april 1993 betreffende oneerlijke bedingen in consumentenovereenkomsten.

51. HvJ EU 14 juni 2012, ECLI:EU:C:2012:349, NJ 2012/512 (Banesto/ Calderón Camino), r.o. 73 respectievelijk 69. Zie ook HvJ EU 30 mei 2013, ECLI:EU:C:2013:341, NJ 2013/487 (Asbeek Brusse \& de Man Garabito/Jahani), r.o. 60 en Asser/Hartkamp 3-I 2019/253. 